\title{
Relocation and investment in R\&D by firms
}

\author{
Juan Carlos Bárcena-Ruiz · María Begoña Garzón
}

Received: 30 October 2012 / Accepted: 10 February 2014 / Published online: 11 March 2014

(C) ISEG 2014

\begin{abstract}
The literature on foreign direct investment has analyzed corporate location decisions when firms invest in R\&D to reduce production costs. Such firms may set up new plants in other developed countries while maintaining their domestic plants. In contrast, we here consider firms that close down their domestic operations and relocate to countries where wage costs are lower. Thus, we assume that firms may reduce their production costs by investing in $R \& D$ and likewise by moving their plants abroad. We show that these two mechanisms are complementary. When a firm relocates it invests more in $\mathrm{R} \& \mathrm{D}$ than when it does not change its location and, therefore, its production cost is lower in the first case. As a result, investment in $\mathrm{R} \& \mathrm{D}$ encourages firms to relocate.
\end{abstract}

Keywords Relocation $\cdot \mathrm{R} \& \mathrm{D} \cdot$ Social welfare $\cdot$ Imperfect competition

JEL Classifications D6 $\cdot \mathrm{F} 16 \cdot \mathrm{J} 51 \cdot \mathrm{L} 13$

J. C. Bárcena-Ruiz · M. B. Garzón

Departamento de Fundamentos del Análisis Económico I, Universidad del País Vasco, UPV/EHU, Avenida Lehendakari Aguirre, 8348015 Bilbao, Spain

e-mail: mariabegona.garzon@ehu.es

J. C. Bárcena-Ruiz

e-mail: juancarlos.barcena@ehu.es 